\title{
Bone Marrow Stem Cell with Potential to Differentiate to Granulocytic Lineage
}

National Cancer Institute

\section{Source}

National Cancer Institute. Bone Marrow Stem Cell with Potential to Differentiate to

Granulocytic Lineage. NCI Thesaurus. Code C42716.

A primitive, undifferentiated blood cell which can undergo division and give rise to white blood cells in the neutrophil, eosinophil or basophil lines. 